\title{
Entrelacs
}

Cinéma et audiovisuel

HS | 2012

Le post-humain et les enjeux du sujet

\section{Vers un inconscient sans sexualité, une conscience sans sujet,un indivis-individu sans sujet}

Gérard Pirlot

\section{(2) OpenEdition}

\section{Journals}

Édition électronique

URL : http://journals.openedition.org/entrelacs/290

DOI : 10.4000/entrelacs. 290

ISSN : 2261-5482

Éditeur

Éditions Téraèdre

\section{Édition imprimée}

Date de publication : 2 février 2012

ISBN : 978-2296567177

ISSN : 1266-7188

\section{Référence électronique}

Gérard Pirlot, « Vers un inconscient sans sexualité, une conscience sans sujet,un indivis-individu sans sujet », Entrelacs [En ligne], HS | 2012, mis en ligne le 01 août 2012, consulté le 02 mai 2019. URL : http://journals.openedition.org/entrelacs/290 ; DOI : 10.4000/entrelacs.290

Ce document a été généré automatiquement le 2 mai 2019.

Tous droits réservés 


\title{
Vers un inconscient sans sexualité, une conscience sans sujet,un indivis- individu sans sujet
}

\author{
Gérard Pirlot
}

1 Le texte complet de cet article est publié dans l'ouvrage :

Post humain et les enjeux du sujet

Editeur : L'HARMATTAN (2 février 2012)

Collection Ouverture Philosophique

ISBN-10 : 2296567177

ISBN-13 : 978-2296567177

\section{RÉSUMÉS}

Se prévalant d'une « approche scientifique » par le seul argument de présenter des chiffres et des raisonnements d'une causalité linéaire désarmante de simplicité, le "post-humain » est une dimension certaine du débat contemporain tant dans l'ensemble de la pensée scientifique, philosophique, qu'artistique qui développe une pensée systémique inspirée du skinnérisme, du néo-béhaviorisme, et aujourd'hui de la robotique neuroscientifique dans un courant proche de la neurophilosophie... 


\section{AUTEUR}

\section{GÉRARD PIRLOT}

Professeur de Psychologie clinique, ancien Psychiatre des Hôpitaux, Psychanalyste Membre de la Société Psychanalytique de Paris et de l'International Psycho-analysis Association 